\title{
Cetacean occurrence near an offshore oil platform in southern Brazil
}

\author{
Marta Jussara Cremer ${ }^{1 *}$ \\ André Silva Barreto ${ }^{2}$ \\ Fernando Augusto Sliva Hardt ${ }^{1}$ \\ Antonio José Tonello Júnior ${ }^{1}$ \\ Roberta Mounayer ${ }^{2}$ \\ ${ }^{1}$ Laboratório de Nectologia, Departamento de Ciências Biológicas \\ Universidade da Região de Joinville \\ Caixa Postal 110, CEP 89240-000, São Francisco do Sul - SC, Brazil \\ ${ }^{2}$ Laboratório de Oceanografia Biológica \\ Centro de Educação Superior de Ciências Tecnológicas da Terra e do Mar \\ Universidade do Vale do Itajaí, Rua Uruguai, 458, CEP 88302-202, Itajaí - SC, Brazil \\ *Corresponding author \\ marta.cremer@univille.net
}

Submetido em 24/10/2008

Aceito para publicação em 19/03/2009

\section{Resumo}

Ocorrência de cetáceos nas proximidades de uma plataforma de petróleo no Sul do Brasil. No Brasil são escassas as informações sobre cetáceos em ambiente oceânico e as plataformas de petróleo podem representar uma importante oportunidade para a obtenção de informações. O presente trabalho foi realizado na plataforma de petróleo P-XIV (Petrobrás) (26 46’02,2”S; 46²7'02,15”W), na área do talude continental, com profundidade de $200 \mathrm{~m}$. No período de julho de 2000 a agosto de 2002 foram registrados 75 avistamentos de cetáceos em 38 dias de esforço. Dentre as espécies identificadas, Tursiops truncatus foi a mais comum, com 53,3\% dos registros. Dentre os misticetos, foi possível identificar com confiança apenas Balaenoptera acutorostrata, com quatro avistamentos (5,3\%). Estas foram as únicas espécies que se aproximaram da plataforma, permanecendo próximo a estrutura. Grande parte dos registros destas espécies foi realizada no período da noite, na área iluminada pelo queimador de gás junto à plataforma. Foi registrado um episódio de interação agressiva entre T. truncatus e $B$. acutorostrata.

Unitermos: Balaenoptera acutorostrata, interação agressiva, plataforma de petróleo, Tursiops truncatus

\section{Abstract}

Information about cetaceans in offshore Brazilian waters is scarce, and oil-rigs could provide an important opportunity to obtain new data. The present work was conducted on the P-XIV oil-rig (Petrobrás) (26 46'02.2"S; $\left.46^{\circ} 47^{\prime} 02.15^{\prime \prime} \mathrm{W}\right)$, located on the border of the continental slope, in an area of $200 \mathrm{~m}$ depth. In the period between July 2000 and August 2002, 75 sightings of cetaceans were recorded during 38 days of effort. Among the species identified, Tursiops truncatus was the most common, corresponding to $53.3 \%$ of the records. Among 
the misticets, only Balaenoptera acutorostrata was identified with accuracy, with 4 records (5.3\%). These were the only species that approached and stayed close to the oil-rig. Many records were made at night, when the gas burner illuminated the area around the oil-rig. We recorded an aggressive interaction involving T. truncatus and B. acutorostrata.

Key words: Tursiops truncatus, Balaenoptera acutorostrata, oil platform, aggressive interaction

Oil platforms are known to be structures that attract a large amount of fish in ocean waters (Hostim-Silva et al., 2002). Thus, cetaceans can occupy areas around these structures in order to exploit the local availability of food resources. Information about the cetaceans that live in offshore Brazilian areas is scarce and limited to few species, mainly because of the operational limitations of this kind of research (Cremer and Simões-Lopes, 1997; Fertl et al., 2003; Moreno et al., 2005; Zerbini et al., 2006; Dalla-Rosa and Secchi, 2007). Observations of cetaceans from oil platforms provide a great opportunity to develop studies concerning the occurrence, diversity and seasonality of species in this area and even their behavior.

The study site was an area of around $3 \mathrm{~km}$ from the P-XIV oil platform (Petrobrás), with $200 \mathrm{~m}$ in depth, on the border of the continental slope (26 $46^{\prime} 02.2^{\prime \prime} \mathrm{S}$; $46^{\circ} 47^{\prime} 02.15^{\prime \prime} \mathrm{W}$ ), southern Brazil (Figure 1). Day surveys were conducted from the platform during all daylight hours (6:00 am to $6: 00 \mathrm{pm}$ ) from the bow or the stern, with the presence of one or two researchers. Night surveys were conducted only near the gas burner that was turned towards $\mathrm{W}$ or E, depending on the wind direction, from $6: 00 \mathrm{pm}$ to 6:00 am. The burner's pipes were often cooled with salt water that dropped onto the surface of the sea from $25 \mathrm{~m}$ above, like a warm shower. The burner provided an intense pool of light around it, attracting large amounts of organisms, especially fish, and allowing cetacean sightings at night. To avoid the fatigue of the researchers, observation efforts of less than 1:30h were made, with intervals of half an hour. Under adverse weather conditions (sea state $>4$ on the Beaufort scale) the effort was interrupted. Upon sighting a cetacean, the species was identified and the number of individuals was recorded, in addition to information related to its behavior.

During the study (July 2000-August 2002), 38 days of observation were conducted, totalling approximately 318 hours of effort. The samplings were conducted during 10 months, but were not systematized because of logistic limitations. Each month, samplings were made on 3 to 6 days. In May, June, September and November, no samplings were conducted. A total of 75 records of cetaceans were made, including $40(53.3 \%)$ of the bottlenose dolphin, Tursiops truncatus, and 4 (5.3\%) of the dwarf minke whale, Balaenoptera acutorostrata (Table 1). These were the only species that approached the oil platform, remaining near it. Many species were not identified because of their distance from the platform, and constituted mere transitory sightings.

In the Gulf of Mexico, T. truncatus seems to be the most common species occurring near oil platforms (Jefferson and Schiro, 2008). In general, there is little published data on the marine mammals near these structures, nor is there much data on underwater noise levels produced by the platforms and their effects on marine mammals (Richardson et al., 1995).

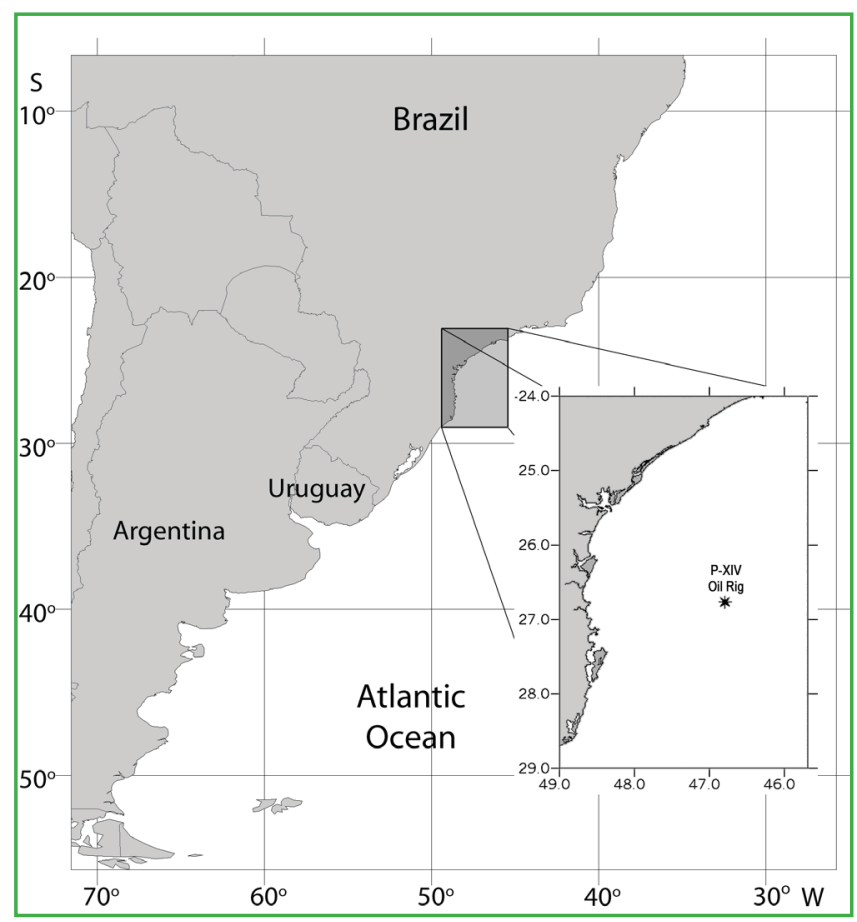

FIGURE 1: Location of the P-XIV oil platform (Petrobrás), on the border of the continental slope $\left(26^{\circ} 46^{\prime} 02.2^{\prime \prime} \mathrm{S}\right.$; 46²7'02.15”W), southern Brazil. 
TABLE 1: Cetacean sightings made between July 2000 and August 2002 from P-XIV oil platform (Petrobrás), southern Brazil.

\begin{tabular}{|c|c|c|}
\hline Species/Taxa & $\begin{array}{c}\text { Number of } \\
\text { sightings }\end{array}$ & Group size \\
\hline Tursiops truncatus & 40 & $\begin{array}{l}\text { between } 1 \text { and } 40 \\
\text { individuals }\end{array}$ \\
\hline $\begin{array}{l}\text { Balaenoptera } \\
\text { acutorostrata }\end{array}$ & 4 & $\begin{array}{l}\text { between } 1 \text { and } 2 \\
\text { individuals }\end{array}$ \\
\hline Delphinus sp. & 2 & 4 and 40 individuals \\
\hline Orcinus orca & 1 & 2 individuals \\
\hline Ziphiidae family & 1 & 2 individuals \\
\hline Delphinidae family & 16 & $\begin{array}{l}\text { between } 1 \text { and } 50 \\
\text { individuals }\end{array}$ \\
\hline Misticeti & 11 & $\begin{array}{l}\text { between } 1 \text { and } 2 \\
\text { individuals }\end{array}$ \\
\hline Total & 75 & \\
\hline
\end{tabular}

Twenty-two sightings of T. truncatus, corresponding to $55 \%$ of total sightings, occurred at night. In this period, group size ranged from 1 to 7 dolphins. During the daytime sessions, 18 sightings (45\%) were made, with group sizes ranging from 3 to 40 dolphins (Table 2). At night, the dolphins stayed for longer periods near the platform, under the light of the gas burner, remaining more than four hours (during the daytime, they remained for only around one hour). The large amount of fish attracted by the burner light probably attracted the dolphins that spent most of the time foraging on the surface. On a few occasions, dolphins were seen catching flying fish (Exocoetidae) slightly above the surface. Tursiops truncatus is a common species on the central and southern Brazilian coast, including some estuaries and rivers (Pinedo et al., 1992). In offshore waters, the occurrence of the species has only been registered opportunistically(e.g. Zerbini et al., 1998). During our daytime observations, it was possible to observe that all T. truncatus individuals showed an intense despigmentation in the caudal peduncle area (Figure 2). Possibly, this could be related to a population pattern of offshore bottlenose dolphins in the South Atlantic. The existence of offshore and coastal types of this species has been identified by certain researchers in other areas based on a number of biological parameters (Ross, 1977; Walker, 1981; Waerebeek et al., 1990). In Brazil, the existence of an offshore population was first proposed by Simões-Lopes (1996), considering color patterns.
Barreto (2000) proposed species variations considering only the analysis of coastal populations.

TABLE 2: Group size and number of sightings of Tursiops truncatus made between July 2000 and August 2002 from P-XIV oil platform (Petrobrás), southern Brazil.

\begin{tabular}{ccc}
\hline $\begin{array}{c}\text { Group } \\
\text { size }\end{array}$ & $\begin{array}{c}\text { Number of sightings } \\
\text { during the daytime }\end{array}$ & $\begin{array}{c}\text { Number of sightings } \\
\text { at night }\end{array}$ \\
\hline 1 & 1 & 5 \\
2 & 3 & 5 \\
3 & 3 & 2 \\
4 & 4 & 6 \\
5 & 1 & 0 \\
6 & 0 & 1 \\
7 & 1 & 3 \\
8 & 2 & 0 \\
20 & 1 & 0 \\
40 & 1 & 0 \\
\hline Total & $\mathbf{1 8}$ & $\mathbf{2 2}$ \\
\hline
\end{tabular}

For the dwarf minke whale, 4 sightings were made, two of which were of lone animals (August and January), occurring during the night period. During the day, a group with two adult animals and a mother-calf pair, both in October, were recorded. Minke whales have a tendency to approach ships (Leatherwood et al., 1976), and this could explain the species' behavior toward the platform. The period that the individuals remained near the platform varied between $30 \mathrm{~min}$ and $3 \mathrm{~h}$. The species is distributed along the eastern coast of South America $\left(5^{\circ}-56^{\circ} \mathrm{S}\right)$, and has a seasonal occurrence on the coast of Brazil with peaks in winter and spring (Zerbini et al., 1997). Sightings made in October and January are probably related to southward movement, from breeding areas to feeding areas, and the record made in August could be related to the opposite movement (Kasamatsu et al., 1995). Northern Brazil $\left(7^{\circ}\right)$ is a breeding area for the species in the South Atlantic (Zerbini et al., 1997). Little is known about the migration routes of $B$. acutorostrata. Minke whales are more common in coastal and inshore areas, but they can be seen offshore (Nowak, 1999; Jefferson et al., 2008). Pinedo et al. (2002) observed B. acutorostrata on two occasions on the Rio Grande do Sul state coast during a cruise (survey) in the spring (November-December). Records of B. acutorostrata carcasses in Santa Catarina state were made along the coast (Cherem et al., 2004). 


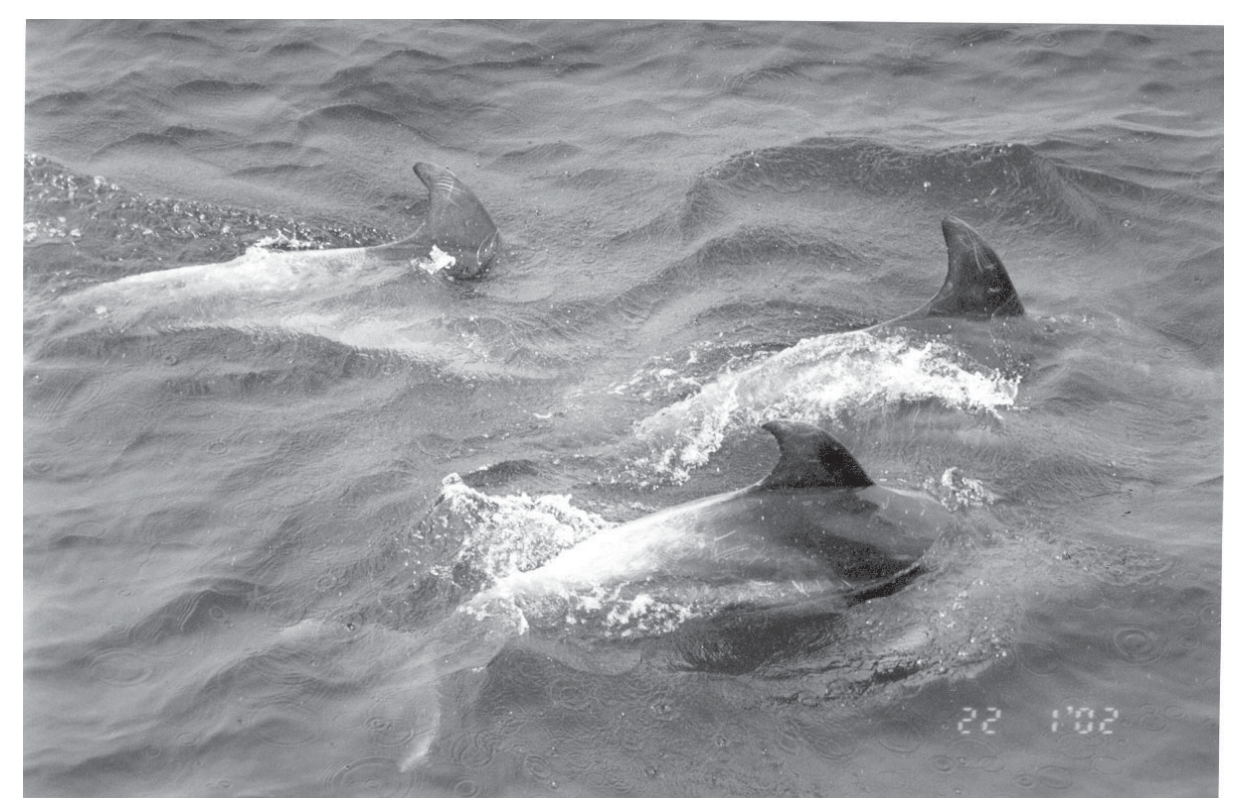

FIGURE 2: Tursiops truncatus group observed near the P-XIV oil platform (Petrobrás); the intense despigmentation in the caudal peduncle area can be observed.

In August, in the night period, an interaction involving $T$. truncatus and $B$. acutorostrata was observed. At 8:36 pm a group with five T. truncatus adults came near the gas burner, remaining in the area and performing an intense feeding activity. They were observed with a fish in their mouth on 10 occasions. At 9:00 pm, a dwarf minke whale came into the area near the gas burner, after the group of dolphins had left. Feeding and resting behaviors were observed and five breathing intervals ranging from $1 \mathrm{~min}$ and $11 \mathrm{sec}$ to $2 \mathrm{~min}$ and $32 \mathrm{sec}$ were also recorded. A few moments later, the group of dolphins came closer again, exhibiting aggressive behavior towards the whale, such as tail slaps and head strikes, as described by Shane (1990), Simões-Lopes (1998) and Wedekin et al. (2004) for the species. The dolphins constantly chased the whale and threatened it with physical violence, apparently changing its route to oblige it to leave the area. The interaction lasted about 3 hours and was videotaped. At 00:45 am, the whale left the area in a NW direction after many attacks by the group of dolphins. It is possible that the dolphins were defending a known place with easily exploitable resources, showing some territoriality. It might be that a part of the T. truncatus population had become specialized to exploit food resources associated with the oil platform. The species is known to develop specialized feeding strategies, as described by Shane (1990) and Simões-Lopes et al. (1998), for example. Inter-specific interactions involving aggressive behavior on the part of bottlenose dolphins have been recorded in connection with other cetaceans such as Stenella frontalis (Herzing and Johnson, 1997), Phocoena phocoena (Ross and Wilson, 1996; Patterson et al., 1998) and Sotalia guianensis (Wedekin et al., 2004). In these situations, it was not exactly clear why attacks took place, but they could be related to practices of infanticide or to food competition.

This is the first record concerning interactions between $T$. truncatus and $B$. acutorostrata. These species are not considered as direct competitors, given the fact that their strategies for obtaining food are different. However, the oil platforms could be used opportunistically by both species as an area of prey concentration in the offshore habitat.

\section{Acknowledgements}

The authors are thankful for the financial and logistical support provided by Petrobrás, the Universidade da Região de Joinville - UNIVILLE, and the Universidade do Vale do Itajaí - UNIVALI. 
Anonymous reviewers made useful suggestions to the manuscript.

\section{References}

Barreto, A. S. 2000. Variação craniana e genética de Tursiops truncatus (Delphinidae, Cetacea) na costa Atlântica da América do Sul. Tese de Doutorado, Universidade do Rio Grande, Brasil, 123pp.

Cherem, J.; Simões-Lopes, P. C.; Althoff, S.; Graipel, M. 2004. Lista dos mamíferos do Estado de Santa Catarina, Sul do Brasil. Mastozoologia Neotropical, 11 (2): 151-184.

Cremer, M. J.; Simões-Lopes, P. C. 1997. Accidental capture of the pantropical spotted dolphin Stenella attenuata (Gray, 1846) (Delphinidae) in the Southwestern South Atlantic Ocean. Biociências, 5 (1): 231-233.

Dalla-Rosa, L.; Secchi, E. R. 2007. Killer whale (Orcinus orca) interactions with the tuna and swordfish longline fishery off southern and southeastern Brazil: a comparison with shark interactions Journal of the Marine Biological Association of the United Kingdom, 87: 135-140.

Fertl, D.; Jefferson, T.; Moreno, I. B.; Zerbini, A. N.; Mullin, K. D. 2003. Distribution of the Clymene dolphin, Stenella clymene. Mammal Review, 33: 253-271.

Herzing D. L.; Johnson, C. M. 1997. Interspecific interactions between Atlantic spotted dolphins (Stenella frontalis) and bottlenose dolphins (Tursiops truncatus) in the Bahamas, 1985-1995. Aquatic Mammals, 23 (2): 85-99.

Hostim-Silva, M.; Fontes, J.; Afonso, P.; Serpa, N.; Sazima, C.; Barreiros, J. P.; Sazima, I. 2002. Plataformas de petróleo: Pontos de encontro de peixes em alto-mar. Ciência Hoje, 183: 20-26.

Jefferson, T. A.; Schiro, A. J. 1997. Distribution of cetaceans in the offshore Gulf of Mexico. Mammal Review, 27 (1): 27-50.

Jefferson, T. A.; Webber, M. A.; Pitman, R. L. 2008. Marine mammals of the world. A comprehensive guide to their identification. Elsevier, San Diego, USA, 573pp.

Kasamatsu, F.; Nishiwaki, S.; Ishikawa. 1995. Breeding areas and southbound migrations of southern minke whales Balaenoptera acutorostrata. Marine Ecology Progress Series, 119: 1-10.

Leatherwood, S.; Caldwell, D. K.; Winn, H. E. 1976. Whales, dolphins, and porpoises of the western North Atlantic: A guide to their identification. U.S. National Marine Fisheries Service, NOAA Technical Report, NMFS Circular 396, 176pp.

Moreno, I. B.; Zerbini, A. N.; Danilewicz, D.; Santos, M. C. O.; Simões-Lopes, P. C.; Lailson-Brito Jr, J.; Azevedo, A. F. 2005 Distribution and habitat characteristics of dolphins of the genus Stenella (Cetacea: Delphinidae) in the southwest Atlantic Ocean. Marine Ecology Progress Series, 300: 229-240.

Nowak, R. M. 1999. Walker's mammals of the world. v.II. $6^{\text {th }}$ ed. The Johns Hopkins University Press, Baltimore, USA, 1936pp.

Patterson, I. A. P.; Reid, R. J.; Wilson, B.; Grellier, K.; Ross, H. M.; Thompsom, P. M. 1998. Evidence for infanticide in bottlenose dolphins: An explanation for violent interactions with harbour porpoises? Proceedings of the Royal Society, 265: 1167-1170.
Pinedo, M. C.; Polacheck, T.; Barreto, A. S.; Lammardo, M. P. 2002. A note on vessel of opportunity sighting surveys for cetaceans in the shelf edge region off the southern coast of Brazil. Journal of Cetacean Research and Management, 4 (3): 323-329.

Pinedo, M. C.; Rosas, F. C. W.; Marmontel, M. 1992. Cetáceos e pinípedes do Brasil. UNEP/FUA, Manaus, Brasil, 213pp.

Richardson, W. J.; Greene Jr., C. R.; Malme, C. I.; Thomson, D. H. 1995. Marine mammals and noise. Academic Press, San Diego, USA, 576pp.

Ross, G. J. B. 1977. The taxonomy of bottlenosed dolphins Tursiops species in South African waters, with notes on their biology. Annual of the Cape Province Museum of Natural History, 11: 135-194.

Ross, H. M.; Wilson, B. 1996. Violent interactions between bottlenose dolphins and harbour porpoises. Proceedings of the Royal Society London, 263: 283-286.

Shane, S. 1990. Behavior and ecology of the bottlenose dolphin at Sanibel Island, Florida. In: Leatherwood, S. \& Reeves, R. R. (Eds). The Bottlenose Dolphin. Academic Press, San Diego, USA, p.245-265.

Simões-Lopes, P. C. 1996. Offshore and coastal bottlenose dolphins in southern Brazil: Preliminary comparisons on coloration. Abstracts of VII Reunião de Trabalho de Especialistas em Mamíferos Aquáticos da América do Sul, Viña del Mar, Chile, p.84.

Simões-Lopes, P. C. 1998. Intraspecific agonistic behavior of Tursiops truncatus (Cetacea, Delphinidae) during dolphin-human interactions in southern Brazil. Biotemas, 2 (11): 164-172.

Simões-Lopes, P. C.; Fábian, M. E.; Menegheti, J. O. 1998. Dolphin interactions with the mullet artisanal fishing in southern Brazil: a qualitative and quantitative approach. Revista Brasileira de Zoologia, 15 (3): 709-726.

Waerebeek, K. V.; Reyes, J. C.; Read, A. J.; McKinnon, J. S. 1990. Preliminary observations of bottlenose dolphins from the Pacific coast of South America. In: Leatherwood, S. \& Reeves, R. R. (Eds). The Bottlenose Dolphin. Academic Press, San Diego, USA, p.143-154.

Walker, W. A. 1981. Geographical variation in morphology and biology of bottlenose dolphins (Tursiops) in the eastern North Pacific. National Marine Fisheries Service. South Fisheries Center Administrative Report No. LJ-81-03C, La Jolla, USA, 52pp.

Wedekin, L. L.; Daura-Jorge, F. G.; Simões-Lopes, P. C. 2004. An aggressive interaction between bottlenose dolphins (Tursiops truncatus) and estuarine dolphins (Sotalia guianensis) in southern Brazil. Aquatic Mammals, 30 (3): 391-397.

Zerbini, A. N.; Secchi, E. R.; Siciliano, S.; Simões-Lopes, P. C. 1997. A review of the occurrence and distribution of whales of the genus Balaenoptera along the Brazilian coast. Report of the International Whaling Commission, 47: 407-417.

Zerbini, A. N.; Bassoi, M.; Secchi, E. R.; Higa, A.; Souza, L. de; Dalla Rosa, L.; Santos, M. C. 1998. Distribution and habitat characteristics of Delphinidae in south eastern and southern Brazil. Abstracts of $8^{\text {a }}$ Reunião de Trabalho de Especialistas em Mamíferos Aquáticos da América do Sul, Olinda, Brazil, p.230.

Zerbini, A. N.; Andriolo, A.; Heide-Jorgensen, M.; Pizzorno, J. L.; Maia, Y.; Vanblaricom, G. R.; DeMaster, D. P.; Simões-Lopes, P. C.; Moreira, S.; Bethlem, C. 2006. Satellite-monitored movements of humpback whales (Megaptera novaeangliae) in the Southwest Atlantic Ocean. Marine Ecology Progress Series, 313: 295-304. 